by 4 per cent per annum since 1949/50. Food consumption per head has increased because of higher purchasing power ; real income per head has during the past four years increased by 2.75 per cent per annum, and about half of this is spent in food.

The policies in the various countries have had the common aim of increasing agricultural output with the single exception of Sweden, where the present output of 107 per cent of domestic food requirements is to be reduced to 90 per cent. Planning has been generally abandoned; there are no longer targets for individual commodities as during the Second World War. What mostly happens now is that farmers are exhorted to produce all they can. A few countries have over-all targets : Great Britain is aiming at 60 per cent increased output over pre-war and has already achieved 56 per cent.

Germany has made the most remarkable recovery. During 1948-49 the agricultural output was nearly 30 per cent below pre-war; during 1954-55 it was 23 per cent above pre-war and was providing 70-75 per cent of the total food requirements in spite of the fact that the agricultural area per head had fallen by nearly one-third in consequence of the flow of refugees from Eastern Germany. There are no specific regulations-only a general requirement that food output must be as large as possible. Of the European exporters of food, Denmark, two-thirds of the export earnings of which are derived from food, aims at improved quality and higher degree of processing so as to increase the value per ton, rather than increasing the number of tons produced. The Netherlands have only the general aim of making agriculture contribute as much as possible to the national wealth: the exports include about 25 per cent of the crop output, 40 per cent of animal produc. tion and more than $\tilde{5} 0$ per cent of horticultural production. In 1954, the total value of these exports was nearly 900 thousand dollars; but.against this was an import of feeding stuffs, other agricultural commodities and human food amounting to 650 thousand dollars. Switzerland and the Irish Republic are among the few countries with a declared demographic aim : both desire to organize their agriculture in such a way as to maintain a large peasant population.

\section{SIXTH INTERNATIONAL CONGRESS OF SOIL SCIENCE}

$\mathrm{T}$ HE Sixth International Congress of Soil Science, organized by the International Society of Soil Science, was held in Paris at the Maison de la Chimie during August 29-September 8, under the presidency of A. Oudin, Inspecteur Général des Eaux et Forêts, France. The Congress was divided into six commissions, the chairmen of which were as follows: Dr. M. B. Ruszel (United States), physics; Dr. A. C. Schuffelen (Holland), chemistry; Dr. P. Simonart (Belgium), biology ; Dr. E. W. Russell (East Africa), fertility ; Dr. A. Muir (Great Britain), classification; and Dr. J. V. Botelho Da Costa (Portugal), soil technology. The Congress attracted the largest number of members, the enrolment being 850 representing fifty countries, as compared with the two previous congresses in Amsterdam and Léopoldville (Congo), where the attendances were 600 and 250 , respectively.
Naturally, the largest group was from France, the next biggest groups being Great Britain, Belgium and the Congo, Holland, West Germany, United States, Spain, Italy, the U.S.S.R., Yugoslavia, East Germany and Switzerland.

The six hundred papers presented at the Congress, most of which were available in printed form, making four separate volumes, covered a wide field of prob. lems, the most important being the influence of climate on soils, soil structure, soil colloids, acid soils, saline and alkali soils and their reclamation, phosphate and potash contents and nutrition, nitrogen transformations, soil micro-organisms, symbiotic, nonsymbiotic, photochemical nitrogen fixation, trace (oligo) elements, forest soils and desert soils. Each author was given a quarter of an hour for outlining his contribution, followed by a discussion lasting 15-20 minutes.

In the afternoon of September 1 there was an interesting colloquium on fertilization and production of paddy, in which several soil scientists from Japan, China, India, the Congo and other tropical parts of the world took active part. A session on the morning of September 8 was devoted to a colloquium on the physico-chemical aspects of mineral nutrition by the plant roots. Some interesting papers were read; but there was no general unanimity of views regarding the mechanism of this process in crop production. As a side-issue of the Congress, there was an important colloquium on leaf analysis and plant nutrient supply, organized by Dr. $P$. Preaud, in which an introductory paper by Prof. T. Wallace was read.

Dr. Bruin, of Holland, put forward the proposal that soil scientists hailing from temperate countries should co-operate in obtaining accurate data on the influence of nitrogenous fertilizers in crop production, and he arranged the convening of a meeting for this purpose in Groningen in November. It is well known that nitrogenous fertilizers are not much used in Asiatic countries, where the majority of the human beings of the world subsist. Moreover, only 3 per cent of the world crop yield has been attributed to artificial nitrogenous fertilizers, as reported at the meeting of the British Association in 1949 in Newcastle (see Nature, 164, 597; 1949): "At present only some three per cent of the world food production can be attributed to the use of nitrogenous fertilizers. To raise the available food by ten per cent, that is to say, one hundred million tons, involves a fourfold increase in supplies of fixed nitrogen, at an approximate capital cost of $£ 1,500,000,000$. This ... would take a minimum of 15 years to achieve". Hence, even to-day world food production has to be mainly attributed to the soil nitrogen present in the soil organic matter or humus, the study of which from different angles attracted the attention of a large number of members of the Congress.

On September 7 there was a whole-day excursion for the study of soil profiles and other topics of agricultural importance in the Paris area. After the Congress, excursions lasting a week were made in different parts of France for the study of soils. In addition, on September 2 several members were taken around the National Agricultural Research Institute at Versailles, and the following week a group visited the Institute at Bondy, $20 \mathrm{~km}$. from Paris, for training French soil scientists for work in the Colonies and research work on problems of Colonial agriculture. 
The general conclusion among members was that this Congress not only contributed to the difficult problem of the amelioration of the world food situation, but also achieved progress in international fellowship and goodwill in the friendly atmosphere of the meeting and parties. The next Congress will be held in the United States in the summer of 1960 under the presidency of Prof. R. Bradfield, of Cornell University.

N. R. DHAR

\section{UNITED NATIONS TECHNICAL ASSISTANCE PROGRAMMES}

$\mathrm{T}$

HE eighth report of the Technical Assistance Board to the Technical Assistance Committee of the United Nations Economic and Social Council* describes the progress and developments during 1955 of the Expanded Programme of Technical Assistance for Economic Development and includes also some details of activities to be undertaken in 1956 and of plans for 1957. The general level of activities was markedly higher, and the contributions of 27.9 million dollars from seventy-one countries, compared with 25 million dollars in 1954, permitted assistance to be given to a hundred and one countries and territories. At the end of the year, some fourteen hundred experts were collaborating with their counterparts in the less-developed countries, and while it is not practicable to isolate the impact of technical assistance on economic development or to measure it precisely, it is clear that significant results have been achieved in many technical assistance activities.

During the year, geological maps of forty-five regions of Bolivia, to be used in prospecting for oil and other minerals, were completed, as was a similar survey in the Yemen. The first geological map of Nepal is being prepared, and a geological survey institute was set up in Afghanistan. Assistance was given in aerial surveys of forests in Brazil and Iraq, and surveys of ground-water resources in Jordan and Pakistan were being expanded, while in Indonesia a team of eight experts assisted the National Planning Board with the preparation of a five-year development plan and investment programme. Expert advice and the assistance of workers trained abroad under fellowships has enabled the production of DD'T and penicillin to be commenced in Chile, Egypt, India, Pakistan and Yugoslavia, while the petrochemical industry in Venezuela has been assisted in the establishment of what will be the largest factory in South America manufacturing fertilizers and insecticides. Assistance given since 1951 to the cottage and small industries of Burma has led to these industries playing an increasingly important part in the country's economy, while throughout the world, nearly a thousand engineers, foremen and skilled workers from all branches of industry have been trained under the worker-trainee programme and large vocational training schools have been opened in Brazil, Guatemala, Haiti, Indonesia and Iran.

Port and shipping experts were assisting the Governments of Jordan and Yemen with the recon-

* United Nations : Technical Assistance Committee. Eighth Report of the Technical Assistance Board. (Economic and Social Council. Official Records: Twenty-second Session, Supplement No. 5.) Pp. vi 104. (New York: United Nations; London: H.M.S.O., 1956.) 1 dollar; 78.; 4 Swiss francs. struction of the ports of Aqaba and Ras-el-Khatib, and nineteen countries received expert advice on the improvement of their civil aviation ; more than 1,140 students completed courses at schools in various countries of the International Civil Aviation Organ. ization during 1952-55. Irrigation and land $\mathrm{re}$ clamation received much attention in Syria and in large river basins such as those of the GangesBrahmaputra, the Tigris and the Euphrates. In a pilot area of 230,000 acres on the right bank of the Ganges in East Pakistan, about one-fifth of the main canal has been excavated with the support of the Colombo Plan and the International Co-operation Administration of the United States, and it is expected that irrigation water will be available in the Kushtia area by the end of this year. Recommendations made by specialists of the Iraqi Development Board on the advice of a geologist of the United Nations Food and Agriculture Organization have led the Government to allocate 4.5 million dollars for drilling wells, fifty of which have been completed or are under construction. A pilot area on the Volta River in the Gold Coast has been brought under experimental cultivation, and in Afghanistan, Egypt, Iraq and Libya demonstrators have been trained to introduce new techniques and improved small tools to farmers. Some of the field workshops in the largescale farm-mechanization plan of Uttar Pradesh in India have increased their output by nearly 300 per cent, and more than five hundred instructors and operators have been trained by international experts.

New varieties of cotton are being tried in Iran, and cultivation trials in Yugoslavia have given a substantially increased yield of cotton per acre. Programmes for increasing the production of wheat and rice have been undertaken in Egypt, and a scheme for developing coffee cultivation has been started in Ethiopia. Assistance given in Central America and Mexico has enabled local authorities to keep the locust plague under control everywhere except Northern Honduras, and the control of olive and fruit flies has been developed in Libya. With the building up of supplies of vaccine to control rinderpest and other animal diseases in Afghanistan, Austria, Burma, Ceylon, Ethiopia, Honduras, India, Iraq, Pakistan, Thailand and Yugoslavia, the emphasis of technical assistance has shifted to the organization of field control schemes.

The training of school teachers has from the start been an important feature of the Expanded Programme of Technical Assistance, and in 1955 more than a thousand rural teachers attended courses in Haiti, while about 2,500 have been trained in the Philippines since work started in 1953. In Indonesia more attention has been paid to training teachers for rural communities, while assistance in teaching science has ranged from the organization of a chemical laboratory and of a scientific instruments centre for the National Council of Research in Egypt to the development of institutions for arid zone research in Brazil and Peru. In Turkey the Institute of Hydrology has now reached the stage when its work can proceed satisfactorily under the direction of national staff, and an international team, which in $1954 \mathrm{com}$. pleted the organization of a scientific and technical documentation centre in Mexico for the LatinAmerican countries, is organizing a similar centre in Egypt to serve the Arab States.

Much assistance has been given to governments in training health staff, the control of communicable 